\title{
Customer Satisfaction Analysis of Banks: The Role of Market Segmentation
}

\author{
Francis Osei $^{1}$, Gloria Ampomah ${ }^{2}$, Collins Kankam-Kwarteng ${ }^{1}$, Daniel Opoku Bediako ${ }^{3}$, \\ Reagan Mensah ${ }^{4}$ \\ ${ }^{1}$ Department of Marketing, School of Business, Kumasi Technical University, Kumasi, Ghana \\ ${ }^{2}$ Department of Revenue, Afigya Kwabre North District Assembly, Kumasi, Ghana \\ ${ }^{3}$ Department of Commercial, L'oreal West Africa, Takoradi, Ghana \\ ${ }^{4}$ Department of Cocoa Health and Extension Division, Ghana cocoa Board, Nyinahin, Ghana
}

\section{Email address:}

oseifrancis1234@gmail.com (F. Osei), ampomahfavour342@gmail.com (G. Ampomah), colkann@gmail.com (C. Kankam-Kwarteng), dopokubediako@gmail.com (D. O. Bediako), reaganmensah@ymail.com (R. Mensah)

\section{To cite this article:}

Francis Osei, Gloria Ampomah, Collins Kankam-Kwarteng, Daniel Opoku Bediako, Reagan Mensah. Customer Satisfaction Analysis of Banks: The Role of Market Segmentation. Science Journal of Business and Management. Vol. 9, No. 2, 2021, pp. 126-138.

doi: 10.11648/j.sjbm.20210902.19

Received: June 3, 2021; Accepted: June 18, 2021; Published: June 30, 2021

\begin{abstract}
In today's competitive banking industry, market segmentation as a serious strategic alternative is very important if players in the banking industry are to achieve customer satisfaction which can influence customer loyalty and profitability. In the study of Ghana Commercial Bank, the investigation focused on how market segmentation has affected customer satisfaction in the Ghana banking industry. The study evaluates the effects of market segmentation on customer satisfaction in the banking industry in Ghana. To achieve the purpose of the study a descriptive research design was adopted. The target population was 200 respondents from five banks (branch) in Kumasi metropolis in Ghana. The primary source of data and secondary source of data was utilized in the entirety of the study. Data collected were analyzed using the Statistical Package for Social Scientists (SPSS) and Smart PLS software. The results proved that there was a positive relationship between geographical segmentation, demographic segmentation, behavioral segmentation on customer satisfaction. The nature of behavioral segmentation provides the opportunity for real-time communication across a wide range of marketing channels including direct mail, email, point-of-sale devices, and mobile channels as well as personal contact at the branch or call center level. The downside of using behavioral data as a marketing driver is that it does require detailed, in-depth data sets, models, and market testing. Also, prices, distribution, and advertising can all be tailored to control variables that are problematic for customers, because today's customers demand simple, convenient, flexible, and timely products and services. The recommendations are intended to represent as a framework for banking industries as they try to provide improved service to their customers.
\end{abstract}

Keywords: Geographical Segmentation, Demographic Segmentation, Behavioral Segmentation, Customer Satisfaction

\section{Introduction}

Business conduct is more complicated than ever and gaining strategic advantages in the industry is also the key trait of exceptionally high success. Any enterprise is looking for this and few have accomplished this fate Saeidi et al, [64]. Modern businesses are all about fighting the fierce battle of the competition for numerous divisions of industry and going on to make accurate changes to these arms at the right moment
Hunger, [35]. To maintain a strategic edge over other operators and rivals, every company works hard to find the best available weapons. It's never so straightforward to find those weapons that are more powerful than ever and definitely need a lot of research and development spending. Companies spend extensively in these sectors and are certainly doing their utmost to ensure that the best combination of industry experts and resources is in their arsenal. Efficient services ensure efficient practices that will definitely give organizations that 
want the advantage they are after. It is often critical for research practitioners and market analysts to detect which techniques and mechanisms are the best commercial arms possible and to allow the most effective use of the tools available to each company. Effective supply chain management, without a doubt, is a very professional business tool to have in any business organization's arsenal. It means that practically everything has safe and increased market appeal and also helps build long-term customer relationships Deepak, and Jeyakumar, [16].

For marketers, particularly those in the service sector, consumer loyalty is a big challenge [33]. Furthermore, once consumers are happy with a new good or service, the probability of doing so again rises Mende et al, [52]. In addition, pleased consumers would most likely speak positively about their relationship with a specific service or product that contributes to favorable advertising Konuk, [41].

The focus is on building consumer satisfaction in today's dynamic retail environment and that means delighting the consumers. Banking is one of the many services that have been increasingly important to the allegiance of customers. This is because the banking industry is, in reality, more effective Kang, and Park, [37]. Marketing management often focuses on the knowledge of client desires and their potential reactions to different components of the marketing mix. Over the past two decades, there has been a sea change in the way business is conducted in the financial sector, especially in the banking sector [12].

Four of the key factors that have constantly changed the activities of banks in Ghana over the past two decades are communication technologies, government decisions and globalization. Extreme rivalry among the twenty-eight licensed banks and other rural banks, as well as savings and credit companies, has been motivated by major rises in the number of banks in Ghana. This is mostly because both of these financial intermediaries offer almost the same products and services. For most banks, the reduction in market share is due to competition; this means that attempts should be taken to encourage consumers to stay loyal rather than investing more money to attract new customers.

In order to distinguish themselves by developing a picture linked to or confined to the availability of a few services or service quality components, Pham et al, [60] proposed that banks adopt market segmentation strategies. Studies have also shown that the following are common criteria for consumer selection; quick and efficient service, friendliness, convenience and security for banking transactions to be conducted. It is among these factors that banks have adopted market segmentation to meet the needs and demands of their customers. In order to keep ahead of competing banks, they have no choice but to provide all customer groups and branches with superior and reliable service to encourage market loyalty and customer retention.

In addition, studies have found that consumers are six times more likely than when they are simply happy to buy back a company's assets over a span of one or two years when they are fully satisfied. In the financial services sector, market segmentation is a critically essential term. The market segmentation methodology defines "the modus operandi" of all functions of customer service.

The speed and success of the steps taken by the BoG to deter the withdrawals and volatility of depositors in local financial markets has been a welcome demonstration of the regulatory measures taken since the financial crisis of 2008 by developed African economies such as Ghana. The Act on Banks and Specialized Deposit Taking Institutions (2016) is the legal basis on which the resolution regime of Ghana was founded to deal with failed banks. It was willing, by virtue of the powers and discretion bestowed on the BoG under that statute, to take the requisite measures to put the failed banks under state ownership. Local banks play a crucial role in the credit flow to local enterprises and the supply to rural and metropolitan areas of payment services; the disorderly collapse of banks may have had a significant negative influence on the real economy Anane, [3].

For banks, it is also rather important to respond to changing customer demands and the business climate. Competition in the Ghanaian banking market, owing to the abundance of banks in Ghana, ensures that consumers already have a choice. As a result, disgruntled clients are more likely to close their accounts to rivals and turn their accounts over Avornyo et al, [4].

In this period of shrinking economies, in this phase of diminishing markets, banks would achieve a comparative edge over their rivals by devoting resources to retaining customers to attract existing customers rather than devoting scarce time and resources to attracting new customers. There are diverse consumer demands across different divisions or market segments of banks.

As it is not possible to independently satisfy the needs of customers, it is also difficult for banks to directly access each customer's needs. In addition, banks must pursue an approach to market segmentation to resolve this issue by focusing in addressing the demands of multiple market sectors rather than individually meeting specific customer requirements. The report therefore takes a critical look at how, using market segmentation, the Ghanaian banking industry aims to achieve customer service excellence. In specific, the study will be confined to the Bank in Ghana, Kumasi which have a successful segmentation policy in order to appease the multiple customer groups in order to sustain and grow the market share of rival banks and other financial services. In direct rivalry with intermediaries.

As Ghana strives to attain the status of a middle-income economy, the role of the financial sector in fostering economic growth cannot be underestimated. Competition in the banking sector in Ghana has been ignited in recent decades by the implementation of the Universal Banking Rule, which has resulted in the proliferation of banks across the world. Increased customer demand and the development of new goods and services now differentiate the banking industry. The presence and viability of financial intermediaries in Ghana mainly depends on what dictates the choice of customers. Players in the Ghanaian banking 
industry need to make efforts to establish stronger relations with those desirable customers in order to draw the most profitable segments of the market, while retaining the average consumer who is part of the mass market. All over the world most multinational banks eg. JPMorgan Chase \& Co, China Construction Bank Corp, Bank of America Corp, Industrial and Commercial Bank of China Ltd, etc., adopt market segmentation and customer relationship management as tactics to better serve their customers and improve customer loyalty. customers face stiff competition. The importance of this study for the researcher implies the extent of the expertise that the researcher can acquire in the service and banking sector in the field of market segmentation. This project also provides a forum for researchers to contribute their expertise to scientific studies in marketing and other areas of academic research. Here are some of the stakeholders who may benefit from the study; Ghana Commercial Bank management and staff can learn more about the effect on customer satisfaction of the market segmentation strategy. The study would recognize the challenges faced by consumers in different management segments to restructure their strategy by designing various products and services for effective customer satisfaction.

This study aims to complete the body of information that can be used to produce further studies by academics and researchers in the academic field. The study completes the body of expertise in the field of banking sector marketing. The marketing departments of other banks in the industry can use the information from the study as a basis for designing business strategies and more specifically market segments for their customers and supporting excellence in customer service [55].

\section{Literature Review}

To gain a better understanding of market segmentation, the study examines a variety of literature and conclusions from diverse researchers on the subject. The study looks at the prereform and post-reform eras of the Ghanaian banking industry to make the literature review more relevant for the objective of this study. There is also a brief profile of Banking industry in Ghana and application of market segmentation in Banking industry in Ghana.

\subsection{Market Segmentation}

Market segmentation means separating a market into smaller consumer units that may have multiple brands or a dynamic mix of ads with diverse criteria and specific features $[10,14,58]$. The primary purpose of market segmentation is the distribution of marketing resources and the power to subdivide the segment in order to attain competitive advantage.

Market segmentation allows organizations to identify the needs of the target customers, satisfy them and even prioritize them. This is also consistent with the theory of marketing, since market segmentation is customer-oriented. Competition segmentation helps enterprises that are more likely to be profitable to more efficiently target their resources. Different communications professors have separate types of hypotheses when it comes to business segmentation. Stylidis et al, [68] suggested that sub-units of clients with a similar range of needs and priorities are included in the market segment. Another theory is that in each industry, markets consist of a number of divisions which consist of homogeneous consumers. The reason is the same with regard to the origin and context of market segmentation.

Ezeh, [21] notes that market segmentation is broken down into smaller classes of consumers with distinct preferences, attributes, or behaviors that typically include distinct brands or marketing blends. The modification of products and marketing strategies to customer desires is increasingly becoming a pillar of strategic marketing. A new challenge to segmentation has been introduced to the increasing volatility in customer behaviour, business diversification leads to sector consolidation, making it harder to create competitive divisions and market effectively through a campaign focus marketing. For the most part, segmentation systems also run in very heterogeneous markets and this adds to the latest implementation problems. Camilleri [9] defined marketing segmentation as a strategy that divides a target market into smaller groups of clients by classifying these groups according to common characteristics.

Nonetheless, some industry segmentations with meanings are given separate terms. A selection of prospective clients is included in the basic market segmentation, as well as how they view and rate the product, based on their buying patterns and how they use the product $[61,73,74]$.

Market segmentation means separating a market into smaller consumer units that may have multiple brands or a dynamic mix of ads with diverse criteria and specific features $[10,14,58]$. The primary purpose of market segmentation is the distribution of marketing resources and the power to subdivide the segment in order to attain competitive advantage.

\subsection{Market Segmentation as Part of Marketing Management}

McDonald and Dunbar, [51] postulated that one of the lasting ideals of sound market management is to win the demand. However, as part of the competitive marketing strategy, the use of market segmentation is not recent, [25] and as part of a campaign implementation process, it has been commonly used in the use of businesses [16, 23, 25, 45] As an important part of marketing management, the widespread use and usage of consumer segmentation within the market reveals its importance and benefit. In reality, Dibb [17] finds that the panacea of contemporary marketing has already been developed as a market segmentation. As part of the brand strategy, McDonald and Dunbar [51] highlighted the value of consumer segmentation, claiming that by appropriate market classification and all subsequent product and maintenance placement, it represents three of the key determinants of business performance. Continuously addressing the expectations and desires of customers and 
investors will be a demanding challenge for any organizations operating in competitive markets. Restricted resources and expertise, which restrict the abilities required to follow a broad marketing viewpoint, further complicate this. Business segmentation enables consumer segments to be mixed into larger purchase groups, creating more efficient and achievable campaign campaigns $[50,74]$.

\subsection{Geographic Segmentation}

McCann [50] indicates that the separation of the industry into separate regional units, such as nations, states, provinces, continents, cities or communities, entails geographic segmentation. The organization may work in one or more sectors, or work as a whole but listen to local variations. To generate even richer representations of consumers and communities, some techniques merge spatial and demographic data. In each region, what marketing and promotional materials work best to meet our target clusters? The firm may decide to try to do business in one or more geographic regions or to operate in all regions, but the variations in needs and priorities between regions should be carefully considered [70, 27, 59]. Different territories have different customs, according to which, based on the local situation, the organization must adopt a marketing plan. Today, many firms, according to the needs of areas, cities and even communities, place their goods, advertisement and promotion. Where there are geographical desires or requirements, spatial segmentation offers valuable distinctions. But it is not only necessary for advertisers to use geographical location as a form of segmentation, as there are also variations between customers in the same geographical area. Therefore, a slightly safer approach for approaching a chosen business area is maybe using several segmentation bases [70, 27, 59].

\subsection{Demographic Segmentation}

The market is divided into groups in demographic segmentation on the basis of variables such as age, family size, period of family life, gender, income, occupation, schooling, faith, ethnicity, generation, nationality and individuals [28, 63, 47]. The recognition of demographic variables to separate the regions of the customer population is justified by many factors [70, 27, 59]. One explanation is that demographic factors are often correlated with the wants, expectations and consumption rates of customers, goods and brand tastes. One is that it is better to live with the demographic variable. Even if the target market is represented non-demographically with regard to the form of personality, the relation to demographic characteristics is still important in order to determine the size of the market and to correctly distribute the media to succeed there. In defining demographic segmentation, based on the definition of seniority, gender, family circle, income, occupation, schooling, faith, ethnicity, generation gap and nationality, the market is divided into different classes. The most widely used basis for distinguishing user segments is the ethnic component [28, 63, 47]. Partly since demographic variables are closely correlated with desire, desires, and consumption rates and thus the other explanation is that it is easier to live with demographic variables than other variables types. Describing whether or not targeting is compatible with nondemographic variables (e.g. type of personality), but it is important to consider demographic factors in order to recognize the dimensions of target markets and to meet target markets efficiently. It could even be an age gap, maybe a little hard to understand as a component. Further clarification would then be provided to illustrate how the production difference has been used for market segmentation. Recently, many scientists have intended to segment markets using the generation gap. This idea stems from the fact that the environmental background of the growth process, such as music, sports, politics and various types of events at this point, has greatly influenced each generation [28, 63, 47]. Those groups are called cohorts by demographers. A cohort's participants share the same key perspectives.

\subsection{Behavioural Segmentation}

Singh and Verma [66] and Lantos [44] show that consumers are split into smaller units based on their awareness and attitude towards the use of a commodity in behavioral segmentation. For multiple items, it is simple to find the consumer. In buying decisions, there are five roles: initiators, influencers, decision leaders, purchasers, and consumers. Different entities play various positions and are crucial in the decision-making process and the consumer's supreme happiness. Behavioral Variables: Many advertisers assume that the most critical place to start is behavioral variables - opportunities, incentives, consumer experience, use rate, satisfaction, status, preparedness of the consumer, and attitude. In building business segments effectively. It will help to build a fuller and coherent picture of a business and its divisions by integrating various behavioral bases $[39,36$, 14]. Buyers are split into subunits during this segmentation on the concept of their mindset and their field of awareness regarding the user responses to a commodity. Many advertisers assume that behavioural indicators, such as usage rate and loyalty status, often have great benefits for consumers, are the easiest starting points for creating consumer segments. [39, 36, 14].

\subsection{Customer Satisfaction}

Customer loyalty has been a serious sales field that in the last twenty years has earned substantial publications from professionals and students. Miswantoet al.,[53] perceive consumer loyalty after buying an industry goods and services as a ranking by the customer. It is about the feeling of satisfaction or dissatisfaction of a person arising from the comparison of the success (results) of a commodity and the importance of its expectations, according to Kotler and Keller [42]. This implies that happiness will vary from individual to individual and would be decided by the consumer. Customer loyalty becomes an overarching 
objective and intent in every business-to-customer setting Munusamy et al., [54]. Given the level of rivalry among companies today, it may also be obvious and significant. Therefore, all companies rely on the need to please clients by providing them goods and services that better match customer desires. Therefore, Rahim Mosahab, [62] agree that consumer satisfaction plays the role of mediator in the customer engagement effects of service efficiency. This suggests an immediate connection between the happiness of consumers and loyalty. A research by Zakarias et al [72] showed that the greater consumer satisfaction with banking services, the greater the tendency to follow a classic loyaltylinked behaviour. Customer satisfaction and loyalty are closely connected, with loyalty being a precedent for satisfaction.

\subsection{Overview of the Banking Industry in Ghana}

As a developing market, Ghana, as an agricultural economy, suddenly became Africa's investment destination due to the emergence of oil in industrial quantities. In order to provide the necessary investment flow of funds, Ghana can also boast a booming financial or banking industry that is well run. The Banking Sector Report (2020) shows that. In December 2019, overall banking sector assets stood at GH 129.06 billion, a year-on-year growth of 22.8 percent compared to 12.3 percent in December 2018. In December 2019, greater growth in overall assets represented faster growth in both nations. And reserves in the international banking market.

Domestic assets increased $23.1 \%$ to reach $\mathrm{GH} \notin 118.69$ billion in December 2019, compared with $12.5 \%$ growth recorded the previous year, while foreign assets increased $19.8 \%$ to reach $10 \mathrm{GH} \varnothing 38$ billion over the same period, up from 9.6\% growth in Higher growth in domestic assets resulted in an increase in the share of domestic assets in total assets to $92.2 \%$ in December 2019 against $90.3 \%$ in December 2018, the share of foreign assets decreasing as a result to $7.8 \%$ against $9.7 \%$ for the same comparative period. Total banks' investments, composed of bills, securities and equity, rose 27.0 percent to $\mathrm{GH} \varnothing 48.45$ billion in December 2019 , from 33.6 percent growth recorded for the same. period in December 2018. The strong growth in total investments in 2018 was largely due to special resolution bonds (long term) issued to Consolidated Bank Ghana (CBG). This led to an increase in long-term investments of $115.8 \%$ in December 2018, while short-term investments contracted by $24.5 \%$. One year after this development, growth in long-term investments (securities) normalized to $30.1 \%$ (GH $\varnothing 33.03$ billion) in December 2019, while short-term investments (bills) increased by $21.1 \%$ to GH $\varnothing 14.98$ billion at the EndDecember 2019. However, higher growth in securities in December 2019 versus short-term bills reflects banks' preference for longer-term instruments in 2019.

According to (Ghana Banking Sector Report, 2019), digital banking has emerged as the fastest growing segment of the financial market in Ghana in recent years and the volume of deposits and withdrawals made via mobile devices has grown to GHS 882 million (\$ 190.6 million) in 2017, a substantial $78 \%$ increase over the previous year. MFIs are also helping to stimulate this trend. Most banks are focusing on promoting existing products to improve visibility and upgrading their banking information technology (IT) platforms to improve service delivery.

GCB Bank Ltd recorded the highest additions (53 new branches) to existing branches in 2017. In the same year, two banks were added to its 161 branches, thus increasing its network to 214 branches across the country, to 1 exclusion of GCB agencies. According to the Ghana Banking Survey (2020), GBC is the largest indigenous bank in the country with an asset base of GHS 6.3 billion which has taken over the activities of UT Bank Ltd. and Capital Bank. GCB management has therefore ensured UT and CAPITAL Bank clients unimpeded access to their funds through their existing channels, adding that "staff of suspected banks will work with GCB staff to ensure transparent transactions". GCB brings its experience, its expertise and its ability to manage a sustainable and profitable institution to the assumed companies.

\subsection{Relationship Between Market Segmentation on Customer Satisfaction}

The findings of the study by Boyd et al. [7] show that reputation, interest charged on loans, and interest on savings accounts are valued higher than other variables such as employee friendliness, modern facilities, and drive-in service.

Clarkson et al. [12] found that consumer attributes and financial service needs fluctuate with age, and that these differences may be leveraged to design marketing strategies for such services.

Demographics, according to Stafford [67], remain one of the most prominent and well accepted criteria for segmenting markets and customers. Even if other segmentation indicators are employed, a marketer must comprehend and grasp demographics in order to estimate the market's size, reach, and efficiency. The study's overall conclusion is that there is a substantial association between demographic variables and perceptions of service quality. The test statistic for income, on the other hand, was not significant [53].

Customer satisfaction and bank service switching behavior are mediated by the importance of a particular bank service to a particular customer and the nature of competitive offerings for different types of banking services available from other banks, according to Manrai and Manrai [49]. Gil et al. [29] found that services encountered have a direct and significant impact on perceived service value, which is the last antecedent to customer happiness in the banking business, in their study.

Since the mid-1980s, academics have been doing research on consumer satisfaction in financial service industries. By inventing the SERVQUAL model, Berry and Parasuraman et al. [5] opened a new window of research in service quality. In the study conducted by Snow et al., [19] their approach was duplicated in several nations with multi-dimensional sectors and found to be near to a big success. Since customer satisfaction is linked to customer retention, particularly in 
markets that are highly competitive and saturated, such as financial services Lopez et al. [46], it is vital to track changes in satisfaction across different subgroups of customers on a regular basis. In this regard, investigations on customer segmentation and bank selection criteria, as well as customer satisfaction, began cautiously with Edgett and Snow, [19] studies. According to the findings, there were significant differences in service expectations for retail banks in Canada across various ethnic groups. Freathy et al. [25] discovered a relationship between segmented clients and their satisfaction based on their cultural background. They also established multicultural market segmentation and produced a Cultural Service Quality Index (CSQI).

\subsection{Hypothesis Statements}

$\mathrm{H}_{1=}$ There is a significant positive relationship between Demographic Market Segmentation (DMS) and customer satisfaction (CS).

$\mathrm{H}_{2}=$ There exist a significant positive relationship between Geographical Market Segmentation (GMS) and customer satisfaction (CS).

$\mathrm{H} 3=$ There exist a significant positive relationship between Behavioral Market Segmentation (GMS) and customer satisfaction (CS).

\subsection{The study Conceptual Model}

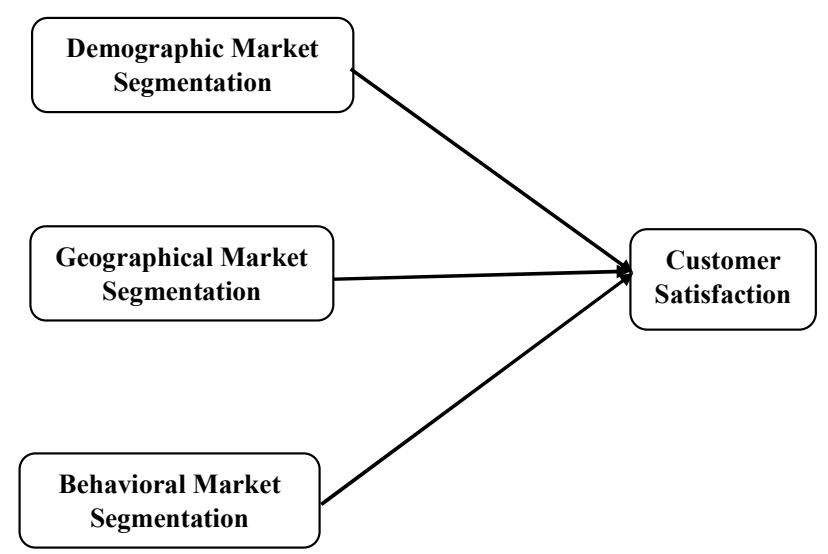

Figure 1. Theoretical framework.

\section{Methodology}

Descriptive research design was employed to assess the effectiveness of market segmentation on customer satisfaction; explanatory study design was also used. Quantitative research method was employed by the study for the purpose of analyzing the data. The study population consisted of customers of commercial banks in Ghana but the study focused on those in the Kumasi Metropolis of Ghana. In achieving the research objectives, the analytical unit were the customers of the target banking industry. The population comprised target customers of banking industry in the Kumasi Metropolis. 200 respondents were drawn from the target banking industry. Due to the fact that the population was not known, the study utilized the convenience sampling technique in selecting respondents. The respondents were approached at their offices, hotels, hospitals, and banking halls where customers conduct transactions; they were willing and ready to communicate their views on the research.

There were a total of 19 questions in this section. Three, five, six, and five items were employed to measure geographic segmentation, behavioral segmentation, and demographic segmentation, respectively. For the subsections of geographic segmentation, behavioral segmentation, and demographic segmentation, a 5-point Likert scale ranging from $1=$ strongly disagree to $5=$ strongly agree was employed. Smart PLS software and the Statistical Package for Science (SPSS) version 21 were used to conduct the analysis. Respondents were asked to communicate their views on various market segmentation strategies, as well as whether they agreed or disagreed with the statements. In the demographic portion, category questions such as gender, age, marital status, educational level, and income level were also used. The goal of Section A was to collect and measure data on the dependent variable of customer satisfaction.

\section{Demographic Characteristics of the Study}

Respondents' demographics included respondent gender, marital status, age, and average processing time. In order to allow generalization of the results of the study, the demographic characteristics were intended to ensure that the sample had the characteristics of the population. Below, the results are discussed.

Table 1. Demographic Characteristics of the Respondents.

\begin{tabular}{llll}
\hline Variables & Categories & & Percent \\
\hline Gender & Male & 134 & 67 \\
& Female & 66 & 33 \\
Marital status & Total & 200 & 100.0 \\
& Single & 105 & 52.5 \\
& Married & 93 & 46.5 \\
& Divorced & 2 & 1 \\
Age & Total & 200 & 100.0 \\
& $18-30$ & 79 & 39.5 \\
& $31-40$ & 53 & 26.5 \\
Average turnaround time & $41-50$ & 68 & 34.0 \\
& Total & 200 & 100.0 \\
& $1-10$ mins & 89 & 44.5 \\
& $11-20$ mins & 87 & 43.5 \\
& $21-30$ mins & 15 & 7.5 \\
& $31-40$ mins & 7 & 3.5 \\
& Above 40 mins & 2 & 1 \\
& Total & 200 & 100.0 \\
\hline
\end{tabular}

Source: Field Survey, 2021.

Table 1 presented information on the demographic characteristic of the respondents and these included the gender, marital status, age, and nationality of the respondents. The results showed that out of $200(100 \%)$ respondents, 134 $(67.0 \%)$ were males and $66(33.0 \%)$ were females. This shows that majority of the respondents were females, as compared to males. Furthermore, the results showed that 105 
$(52.5 \%)$ of the respondents were single, 93 (46.5\%) were married and $2(1 \%)$ were divorced. Thus, the majority of the respondents were singles, while the least were divorced. Additionally, the results showed that 79 (39.5\%) of the respondents were between the ages of 18-30, and 53 (26.5\%) 31-40, were between 68 (34\%) were between 41-50. This shows that majority of the respondents were between 18-30, while the least were above 50 .

Furthermore, the results show that out of $200(100 \%)$ respondents, $89(44.5 \%)$ respondents spend 1-10 minutes, 87 (43.5\%) of the respondents spend 11- 20 minutes, 15 (7.5\%) of the respondents spend 21- 30 minutes, 7 (3.5\%) of the respondents spend 31- 40 minutes and $2(1 \%)$ of the respondents spend above 40 minutes at the banks. Thus, the majority of the respondents spend 1-10 minutes at the bank.

\subsection{Analysis and Results of Structural Equation Modelling}

To evaluates the effects of market segmentation on customer satisfaction in the banking industry in Ghana, this study used partial least squares (PLS) and structural equation modeling (SEM). The latent variables are controlled in the SEM technique, and measurement error is explicitly included in the estimation model (Henseler et al, [34]. According to Gefen et al. [26], SEM is rigorous for business and management research since it verifies instruments, justifies construct links, and includes latent variables in the estimation. This is why we decided to use SEM to evaluate our model. The SEM is done under PLS, whereas the latent variable is run using a variance-based approach. According to Hair, et al [32], the best method of choice for business and management studies is PLS. This is because the PLS estimates employ dispersion (variance) instead of mean or correlation to indicate the magnitude and direction of the link, which helps to avoid parameter estimation errors that are typical in regression analysis Calantone et al, [8].

\subsection{Validity and Reliability Results}

A reliability test was performed to ensure the level of consistency in the assessment of the targeted latent construct. Cronbach's alpha was used to measure the reliability, and the results were higher above the acceptable criterion of $>.70$, indicating that the instruments were highly reliable (Hair et, [32].

Table 2. Construct Reliability and Validity.

\begin{tabular}{|c|c|c|c|c|c|}
\hline Research constructs & Cronbach's alpha & Rho_A & $\mathbf{C R}$ & AVE & Loadings \\
\hline Behavioural Market Segmentation & 0.844 & 0.919 & 0.897 & 0.693 & \\
\hline BMS1 & & & & & 0.823 \\
\hline BMS2 & & & & & 0.560 \\
\hline BMS3 & & & & & 0.951 \\
\hline BMS4 & & & & & 0.936 \\
\hline Customer Satisfaction & 0.991 & 0.991 & 0.993 & 0.966 & \\
\hline CS1 & & & & & 0.990 \\
\hline CS2 & & & & & 0.976 \\
\hline $\mathrm{CS} 3$ & & & & & 0.979 \\
\hline CS4 & & & & & 0.989 \\
\hline CS5 & & & & & 0.980 \\
\hline Demographic market Segmentation & 0.953 & 0.956 & 0.966 & 0.876 & \\
\hline DMS1 & & & & & 0.877 \\
\hline DMS2 & & & & & 0.955 \\
\hline DMS3 & & & & & 0.961 \\
\hline DMS4 & & & & & 0.949 \\
\hline Geographical Market Segmentation & 0.922 & 0.933 & 0.945 & 0.812 & \\
\hline GMS1 & & & & & 0.867 \\
\hline GMS2 & & & & & 0.873 \\
\hline GMS3 & & & & & 0.965 \\
\hline GMS4 & & & & & 0.897 \\
\hline
\end{tabular}

Source: Field data (2021).

The validity and reliability of the goodness of measure were assessed prior to the data analysis. Validity assesses how well an instrument measures the particular notion it is designed to examine, whereas reliability checks how consistent an instrument assesses its construct Sekaran, [65]. Cronbach's alpha is a test used to determine how reliable a set of measurements is. As can be seen in Table 2, all of the alpha values are more than 0.6 , as Gliem et al, [30] predicted. The items in the questionnaire can be determined to be reliable for use in the survey. A composite reliability of 0.70 or above is deemed acceptable, similar to Cronbach's alpha for the reliability estimate of internal consistency Fornell and Larcker [24]. As a result, we may say that the measurements are accurate. 
Table 3. Discriminant validity.

\begin{tabular}{lllll}
\hline & $\begin{array}{l}\text { Behavioural Market } \\
\text { Segmentation }\end{array}$ & Customer Satisfaction & $\begin{array}{l}\text { Demographic Market } \\
\text { Segmentation }\end{array}$ & $\begin{array}{l}\text { Geographical Market } \\
\text { Segmentation }\end{array}$ \\
\hline BMS & 0.832 & & & \\
CS & 0.931 & 0.983 & 0.936 & 0.901 \\
DMS & 0.795 & 0.891 & 0.865 & \\
GMS & 0.931 & 0.963 & & \\
\hline
\end{tabular}

By assessing the correlation between the measurements of possibly overlapping constructs, discriminant validity is evaluated. Discriminant validity is a measure of how well items distinguish across conceptions or assess different concepts. The AVE shared between each construct and its measures should be more than the variance shared between the construct and other constructs in the model, and items should load more heavily on their own constructs in the model Compeau \& Higgins, [13]. This research is in line with this claim because, for each construct, all the constructs met the discriminant validity with the AVE greater than the square correlation with the other constructs as shown in the above table. This is the matrix for inter-construct correlation.

Table 4. Total effects.

\begin{tabular}{|c|c|c|c|c|}
\hline & Behavioural Market Segmentation & Customer Satisfaction & Demographic Market Segmentation & Geographical Market Segmentation \\
\hline BMS & & 0.276 & & \\
\hline CS & & & & \\
\hline DMS & & 0.239 & & \\
\hline GMS & & 0.499 & & \\
\hline
\end{tabular}

The positive reading of all the variables confirm that the model fits the data perfectly.

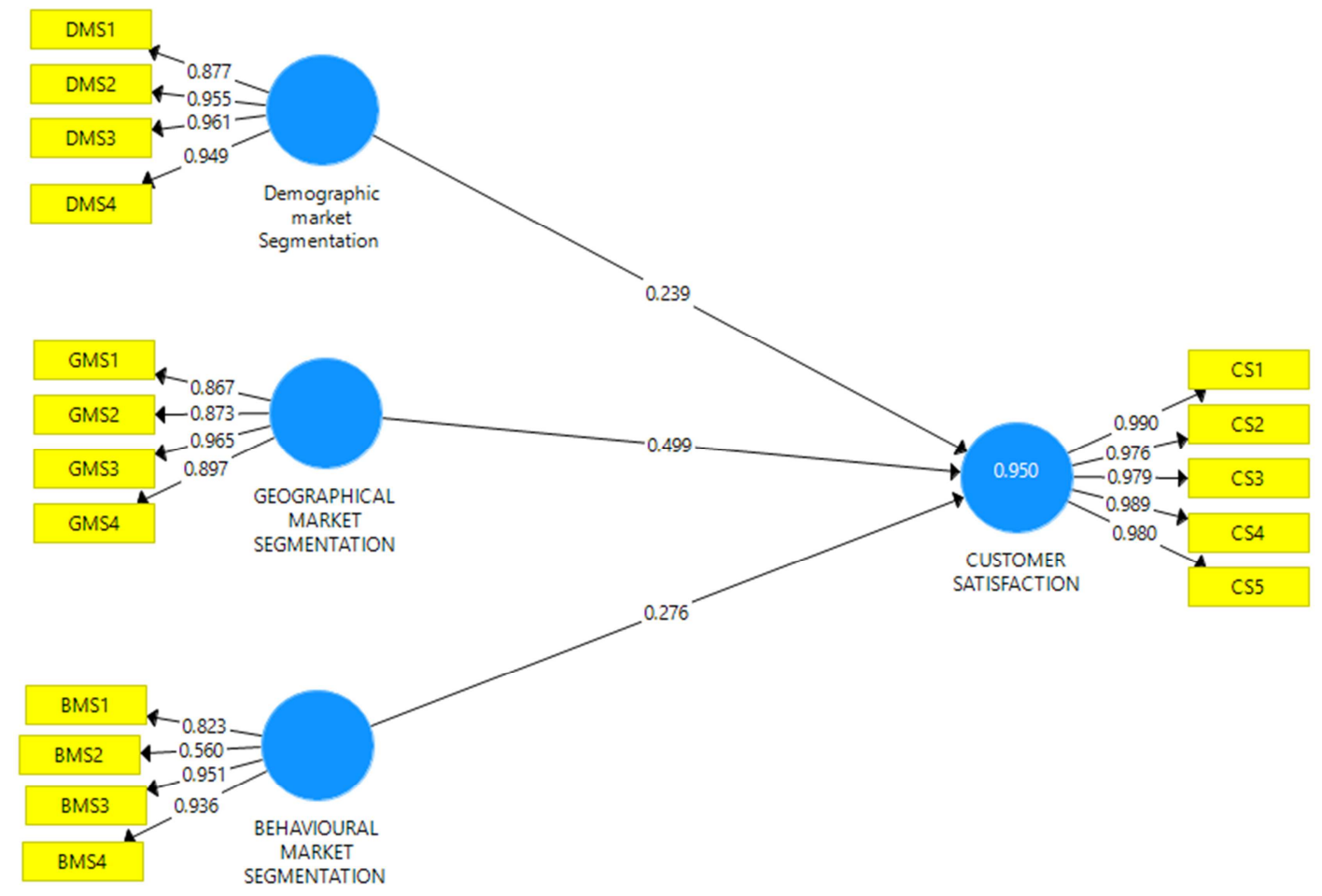

Figure 2. Regression weights of Path Analysis of proposed Structural Model.

Table 5. Structural model from the hypothesized relationships.

\begin{tabular}{llllll}
\hline Study's hypothesis & Hypothesis & Path Coefficient & T Statistics & P Values & Supported/Rejected \\
\hline DMS $->$ CS & H1 & 0.228 & 3.629 & 0.000 & Supported \\
GMS -> CS & H3 & 0.520 & 4.514 & 0.000 & Supported \\
BMS -> CS & H3 & 0.267 & 4.437 & 0.000 & Supported \\
\hline
\end{tabular}

Note: BMS=Behavioural Market Segmentation; CS=Customer Satisfaction; DMS=Demographic Market Segmentation; GMS=Geographical Market Segmentation. ${ }^{*}$ Significance at $\mathrm{p}<0.05 ;{ }^{* *}$ Significance at $\mathrm{p}<0.01 ;{ }^{* * *}$ Significance at $\mathrm{p}<0.001$. 


\subsection{Discussion}

The purpose of this study is to evaluates the effects of market segmentation on customer satisfaction in the banking industry in Ghana. According to the results of study we came to know that market segmentation has positive impact on customer satisfaction in the banking industry in Ghana.

The results of the study indicate that demographic segmentation has a relationship with customer satisfaction of respondents was assessed and the finding revealed that there was a positive and significant relationship between them, supporting the stated goal. The study path coefficient was 0.228 , $t$-value of 3.629 significant at $t \geq 1.65$, and $p$ value of 0.000 at a high significance level of $\mathrm{p}<0.05$. Segmentation has been one of the dominant principles of both marketing theory and experience, in line with the observational analysis of other scholars such as $[1,40]$. Segmentation is taken into account in the banking system, as in any other service field, as an essential way of operationalizing the marketing principle and providing guidance for the marketing policy of a bank and the distribution of capital between markets and services. Consumer segmentation, in principle, is the practice of splitting a market into different categories of individuals or organizations who have one or more common responses to some marketing mix components Amoah, and Radder, [2]. The segmentation process implies dividing the entire industry into homogeneous divisions, suggesting that there are two schools of thinking by choosing the target market segmentation literature. Next the behavioral-oriented school deals with the recognition and reporting of generalizable discrepancies between buyers' categories. These differences may describe the underlying function of consumer behavior $[30,9]$. Second, a choice-oriented school that no longer stresses whether there are consumer variations, nor how these differences can be used to improve the productivity of the bank's marketing services Edinah, [20]. In fact, these two approaches do not appear to be mutually exclusive; they converge in many segmentation studies in particular. A normative problem, for example, usually motivates analysis that aims to apply to behavioral theory. A decision-oriented research, in contrast, can theoretically contribute to an interpretation of consumer segments. Numerous experiments have been carried out in relation to the banking communications literature on the segmentation of individual customers using both behavioral and decision-oriented approaches Boyd et al, [6]

Another important finding of this study is that geographic segmentation has a relationship with customer satisfaction and the level of geographic segmentation of respondents was assessed and the result revealed that there was a positive and significant relationship between them, which supports the study. This indicates that more respondents agreed that the bank should use marketing strategies to improve customer satisfaction. The study path coefficient was 0.520 , t-value of 4.514 significant at $t \geq 1.65$, and $p$ value of 0.000 at a high significance level of $p<0.05$. This demonstrates how support segmentation leads to satisfied customers by providing a variety of direct benefits to the practitioner. This is in line with the empirical analysis of other researchers such as Kara and Kaynak, [38] found that market segmentation attempts to separate markets consisting of individuals into classes with relatively homogeneous and heterogeneous characteristics within each collection or segment. Supporting an identified set of variables within segments. The concept of market segmentation with zeal has been adopted by scholars and marketing experts. It is recognized that advantages include an incentive to obtain a better perspective of a preferred market, innovative methods of estimation of consumer conduct, and an improved potential to recognize and exploit new market opportunities for commercial purposes (Dolnicar et al, [18]. It is likely that it will be extremely useful for those who wish to exploit consumer appetite for a product to divide markets into various groups of consumers or prospective buyers who react differently to shifts in marketing mix variables. OR a specialized facility. As Naughton et al, [57] point out the usefulness of segmentation depends on the acquisition of detectable, available, substantial, exploitable and distinguishable segments. Kotler et al., [42] refer to a concerted measurable group where both the scale of the segment and the purchasing force involved are often quantified. The marketing agency must be able to effectively enter and serve a segment in order for it to be available. Furthermore, to help the marketing entity's creation of marketing mix strategies that are distinct from other segmentfocused strategies, the segment must be relevant, relatively large and profitable. There the segment must also be actionable, the marketing entity should design appropriate marketing campaigns to target and represent the segment, and they must react differently to various marketing triggers for the segments to be differentiable.

This study has demonstrated that behavioral segmentation has a relationship with customer satisfaction and the level of behavioral segmentation of respondents was assessed and the result revealed that there was a positive and significant relationship between them, supporting the stated goal. This has shown that target consumers for a product or campaign can be grouped together based on their behavioral characteristics. This then provides a support, $\beta=.402(\mathrm{t}=4.446$, $\mathrm{p}<.000$ ). The study path coefficient was 0.228 , t-value of 3.629 significant at $t \geq 1.65$, and $p$ value of 0.000 at a high significance level of $p<0.05$. This is consistent with the empirical analysis of other researchers such as Gogoi, and Jyoti, [31] which supports the purpose of market segmentation is to group consumers into segments with common purchase needs and habits, so that a given marketing campaign can target each segment. The idea aims to fill the divide between diverse consumer demands and organizational capital by facilitating the creation of independent product and marketing offerings to address the needs of different groups of consumers. Marketing research indicates that segmentation leads to more pleased consumers, as it gives a number of apparent advantages to the 
practitioner: greater comprehension of consumer demands, more appropriate budget distribution, easier recognition of market prospects, and better tuned and positioned marketing programs (Kotler, et al [43]).

\section{Conclusion}

In other words, if you only look at demographics, you don't understand the differences between customers. Recognizing that demographic and socio-economic segmentation play an important role in financial asset purchasing habits, the value of psychographic characteristics must also be understood in order to maximize a brand's awareness in the market. A mature market is finance. In part, there are only two ways to dramatically increase market share. One is buying from a rival. The second is to take the business by aggressive marketing tactics from its rivals. Using behavioral data is a superior tool from a marketing standpoint, both in its ability to increase revenue and in its ability to do so at a much lower cost than large-scale communication methods. A financial institution can no longer simply target social, demographic or psychographic factors. In order to distinguish between customers who may appear clustered in similar segments, Researchers must use behavioral cues. Researchers have found that it is more costly to attract new consumers than to retain existing ones [56, 22, 69] and that there is tremendous market loyalty and rewards for current customers. Furthermore, Mahmoud et al, [48] concluded that customer value and loyalty are enhanced by the performance of a business segmentation practice, which is the requirement for competitive advantage. Present literature has stressed that the practice of market segmentation and customer loyalty in an organization's life is a requirement for corporate growth and competitive advantage Vidili, [71]; Mahmoud, [48]. It is rational to conclude from the discussion and review to date that these banks and other banks in Ghana can only survive in today's unpredictable and turbulent business climate by paying attention. practicing and effectively implementing and monitoring the Market Satisfaction Components to ensure their continued use and implementation to ensure customer satisfaction. If banks are able to recognize the services that customers need, and design and implement strategies to meet those needs, they will gain a competitive advantage over others.

\section{Recommendations for Further Studies}

Based on the above findings, it is advised to closely analyze the operating environment and ensure that the customer pool of the bank is segmented efficiently and effectively in order to properly plan its service and product offerings. A suitable corporate profile, provision of just-intime service, employee-client relationship, reliable and productive use of referrals and simple account opening formalities should be embraced by dominated and less dominated banks to generate trust and keep customers satisfied, which helps maintain old customers and win back customers. For bank managers, the importance of customer loyalty has become a core concern as competition in the Ghanaian banking sector intensifies. Therefore, the need to establish an enduring friendship that is mutually beneficial with trustworthy clients should not be ignored. The concept of market segmentation and customer retention is very important for bank managers to understand, as happy consumers are less likely to leave, less expensive to maintain, than to attract new customers with a constructive and enthusiastic word of mouth. In terms of this the researcher also suggested that there is a clear desire for a group of individuals, that they wish to buy or procure a specific commodity, that they want to pay for what they need to receive this product, and that they have the approval to purchase this product.

From the issues posed by these four criteria which are used to determine the submission, the definition of 'public' can be achieved. The idea of customer marketing, as a collection of existing clients and future debts, is that they have saturated desires or wishes, they have the will and incentive to buy, and religion will serve them and fulfill them.

In addition to the above, a thorough examination of the operating environment should be performed to ensure that the bank's customer pool is segmented effectively and efficiently to help plan its service and product offerings. Dominated and less dominated banks should adopt an appropriate corporate image, just-in-time service delivery, employee-customer partnership, effective and efficient use of referrals, and easy account opening formalities to build loyalty and satisfying customers, which in turn helps retain old customers and gain new customers. Policy concerns also include strengthening market segmentation activity and customer satisfaction of Ghanaian banks. The results contribute to the general body of knowledge and provide a basis for further theory and research growth, in particular market orientation and customer loyalty and bank retention.

\section{References}

[1] Allenby, G., Fennell, G., Bemmaor, A., Bhargava, V., Christen, F., Dawley, J.,... \& Yang, S. (2002). Market segmentation research: beyond within and across group differences. Marketing Letters, 13 (3), 233-243.

[2] Amoah, F., \& Radder, L. (2018). Profile Variables as a Basis for Segmenting Markets: A Guesthouse Perspective. Journal of Economics and Behavioral Studies, $10(3(\mathrm{~J}))$, 60-73.

[3] Anane, A. K. (2019). Sustainability for Portfolio Optimization.

[4] Avornyo, P., Fang, J., Odai, R. O., Vondee, J. B., \& Nartey, M. N. (2019). Factors Affecting Continuous Usage Intention of Mobile Banking in Tema and Kumasi. International Journal of Business and Social Science, 10 (3).

[5] Berry, L. L., Parasuraman, A., \& Zeithaml, V. A. (1988). The service-quality puzzle. Business horizons, 31 (5), 35-43. 
[6] Boyd, B., \& Dyhr Ulrich, A. M. (2014). Market entry strategies into the BRIC countries-a comparison of Danish family and non-family businesses. International Journal of Globalisation and Small Business, 6 (1), 15-36.

[7] Boyd, W. L., Leonard, M., \& White, C. (1994). Customer preferences for financial services: an analysis. International Journal of Bank Marketing.

[8] Calantone, R. J., Graham, J. L., \& Mintu-Wimsatt, A. (1998). Problem-solving approach in an international context: antecedents and outcome. International Journal of Research in Marketing, 15 (1), 19-35.

[9] Camilleri, M. A. (2018). Market segmentation, targeting and positioning. In Travel marketing, tourism economics and the airline product (pp. 69-83). Springer, Cham.

[10] Cavusgil, S. T. (2021). Advancing knowledge on emerging markets: Past and future research in perspective. International Business Review, 101796.

[11] Christopher, M. (2016). Marketing: an introductory text. Macmillan International Higher Education.

[12] Clarkson, C., Mirosa, M., \& Birch, J. (2018). Consumer acceptance of insects and ideal product attributes. British Food Journal.

[13] Compeau, D. R., \& Higgins, C. A. (1995). Computer selfefficacy: Development of a measure and initial test. MIS quarterly, 189-211.

[14] De Mooij, M. (2019). Consumer behavior and culture: Consequences for global marketing and advertising. Sage.

[15] Deepak, R. K. A., \& Jeyakumar, S. (2019). Marketing management. Educreation Publishing.

[16] Dibb, S. (1998). Market segmentation: strategies for success Marketing Intelligence \& Planning.

[17] Dibb, S. (2005). Market segmentation implementation barriers and how to overcome them. The marketing review, 5 (1), 1330 .

[18] Dolnicar, S., Grün, B. and Leisch, F., 2018. Market segmentation analysis: Understanding it, doing it, and making it useful (p. 324). Springer Nature.

[19] Edgett, S., \& Snow, K. (1996). Benchmarking measures of customer satisfaction, quality and performance for new financial service products. Journal of Services Marketing.

[20] EDINAH BARONGO, N. Y. A. B. W. A. R. I. (2017). EVALUATION OF THE EFFECT OF MARKET SEGMENTATION ON SALES PERFORMANCE OF THE BANKING INDUSTRY; A SURVEY OF COMMERCIAL BANKS IN KISII TOWN, KISII COUNTY.

[21] Ezeh, L. N., Abamara, N. C., Ugwuoju, A. C., \& Obike, U. B. (2017). Influence of personality and educational level on Nigerian consumers preference for foreign goods. Research on Humanities and Social Sciences, 7, 4.

[22] Farris, P. W., Bendle, N., Pfeifer, P. E., \& Reibstein, D. (2010). Marketing metrics: The definitive guide to measuring marketing performance. Pearson Education.

[23] Ferrell, O. C., \& Hartline, M. (2013). Marketing strategy, text and cases. Cengage Learning.
[24] Fornell, C., \& Larcker, D. F. (1981). Structural equation models with unobservable variables and measurement error: Algebra and statistics.

[25] Freathy, P., \& O'connell, F. (2000). Market segmentation in the European airport sector. Marketing Intelligence \& Planning.

[26] Gefen, D., \& Straub, D. (2005). A practical guide to factorial validity using PLS-Graph: Tutorial and annotated example. Communications of the Association for Information systems, $16(1), 5$.

[27] Giaoutzi, M., Nijkamp, P., \& Storey, D. J. (Eds.). (2016). Small and medium size enterprises and regional development. Routledge.

[28] Gichuru, M. J., \& Limiri, E. K. (2017). Market Segmentation As A Strategy For Customer Satisfaction And Retention. International Journal of Economics, Commerce and Management. United Kingdom Vol. V, (12), 544-553.

[29] Gil, I., Berenguer, G., \& Cervera, A. (2008). The roles of service encounters, service value, and job satisfaction in achieving customer satisfaction in business relationships. Industrial marketing management, 37 (8), 921-939.

[30] Gliem, J. A., \& Gliem, R. R. (2003). Calculating, interpreting, and reporting Cronbach's alpha reliability coefficient for Likert-type scales. Midwest Research-to-Practice Conference in Adult, Continuing, and Community Education.

[31] Gogoi, D., \& Jyoti, B. (2020). Changing Consumer Behavior: Segmenting Consumers to Understand Them Better. International Journal of Management, 11 (5).

[32] Hair Jr, J. F., Sarstedt, M., Hopkins, L., \& Kuppelwieser, V. G. (2014). Partial least squares structural equation modeling (PLS-SEM): An emerging tool in business research. European business review.

[33] Hallikainen, H., Savimäki, E. and Laukkanen, T., 2020. Fostering B2B sales with customer big data analytics. Industrial Marketing Management, 86, pp. 90-98.

[34] Henseler, J., Ringle, C. M., \& Sinkovics, R. R. (2009). The use of partial least squares path modeling in international marketing. In New challenges to international marketing. Emerald Group Publishing Limited.

[35] Hunger, J. D. (2020). BM-542 Essentials of Strategic Management.

[36] Ibrahim, A., Knox, K., Rundle-Thiele, S., \& Arli, D. (2018). Segmenting a water use market: theory of interpersonal behavior insights. Social Marketing Quarterly, 24 (1), 3-17.

[37] Kang, M., \& Park, M. J. (2019). Employees' judgment and decision making in the banking industry: The perspective of heuristics and biases. International Journal of Bank Marketing.

[38] Kaynak, E., \& Kara, A. (2012). Assessing tourism market potential in a dynamic emerging economy. Asia Pacific Journal of Marketing and Logistics.

[39] Keller, K. L. (2016). Unlocking the power of integrated marketing communications: How integrated is your IMC program?. Journal of Advertising, 45 (3), 286-301.

[40] Kımıloğlu, H., Nasır, V. A., \& Nasır, S. (2010). Discovering behavioral segments in the mobile phone market. Journal of Consumer Marketing. 
[41] Konuk, F. A. (2019). The influence of perceived food quality, price fairness, perceived value and satisfaction on customers' revisit and word-of-mouth intentions towards organic food restaurants. Journal of Retailing and Consumer Services, 50, 103-110.

[42] Kotler, P., \& Keller, K. L. (2006). Marketing Management 12e. France: Edition Pearson Education.

[43] Kotler, P., Kartajaya, H., \& Setiawan, I. (2019). Marketing 3.0: From products to customers to the human spirit. In Marketing Wisdom (pp. 139-156). Springer, Singapore.

[44] Lantos, G. P. (2015). Consumer behavior in action: Real-life applications for marketing managers. Routledge.

[45] Lin, C. F. (2002). Segmenting customer brand preference: demographic or psychographic. Journal of Product \& Brand Management.

[46] Lopez, J., Hart, L. K., \& Rampersad, A. (2007). Ethnicity and customer satisfaction in the financial services sector. Managing Service Quality: An International Journal.

[47] Madeira, A. B., Da Silveira, J. A. G., \& Toledo, L. A. (2015). Marketing segmentation: your role for diversity in dynamical systems. GESTÃO. Org, 13 (1), 71-78.

[48] Mahmoud, M. A. (2019). Gender, e-banking, and customer retention. Journal of global marketing, 32 (4), 269-287.

[49] Manrai, L. A., \& Manrai, A. K. (2007). A field study of customers' switching behavior for bank services. Journal of retailing and consumer services, 14 (3), 208-215.

[50] McCann, P. (2016). The UK regional-national economic problem: Geography, globalisation and governance. Routledge.

[51] McDonald, M., \& Dunbar, I. (2013). Market segmentation. Chichester: John Wiley \& Sons.

[52] Mende, M., Scott, M. L., van Doorn, J., Grewal, D., \& Shanks, I. (2019). Service robots rising: How humanoid robots influence service experiences and elicit compensatory consumer responses. Journal of Marketing Research, 56 (4), 535-556.

[53] Miswanto, M., \& Angelia, Y. R. (2017). The influence of service quality and store atmosphere on customer satisfaction. Jurnal Manajemen dan Kewirausahaan, 19 (2), 106-111.

[54] Munusamy, J., Chelliah, S., \& Mun, H. W. (2010). Service quality delivery and its impact on customer satisfaction in the banking sector in Malaysia. International journal of innovation, management and technology, 1 (4), 398.

[55] Muumob, D. D. (2016). Market Orientation Practices and Customer Satisfaction in the Ghananian Banking Sector (Doctoral dissertation, University of Ghana).

[56] Narteh, B. (2012). Internal marketing and employee commitment: Evidence from the Ghanaian banking industry. Journal of Financial Services Marketing, 17 (4), 284-300.

[57] Naughton, P., McCarthy, M., \& McCarthy, S. (2017). Reducing consumption of confectionery foods: A post-hoc segmentation analysis using a social cognition approach. Appetite, 117, 168-178.

[58] Oztaysi, B., Gurbuz, T., Albayrak, E., \& Kahraman, C. (2016). Target Marketing Strategy Determination for Shopping Malls
Using Fuzzy ANP. Journal of Multiple-Valued Logic \& Soft Computing, 27.

[59] Peterson, M. F., \& van Iterson, A. (2015). Differences in work goals among regions of the Netherlands and Germany: functional, institutional and critical event influences. The International Journal of Human Resource Management, 26 (2), 277-297.

[60] Pham, L., Limbu, Y. B., Bui, T. K., Nguyen, H. T., \& Pham, H. T. (2019). Does e-learning service quality influence elearning student satisfaction and loyalty? Evidence from Vietnam. International Journal of Educational Technology in Higher Education, 16 (1), 1-26.

[61] Piercy, N. F. (2016). Market-led strategic change: Transforming the process of going to market. Taylor \& Francis.

[62] Rahim Mosahab, P. C. (2010). Service Quality, Customer Satisfaction and Loyalty: A Test of Mediation.

[63] Rahmawati, R. (2019). Profiling Shopping Mall Costumer Based on Demographics and Shopping Motivation. J-MKLI (Jurnal Manajemen dan Kearifan Lokal Indonesia), 3 (2), 74 83.

[64] Saeidi, P., Saeidi, S. P., Sofian, S., Saeidi, S. P., Nilashi, M., \& Mardani, A. (2019). The impact of enterprise risk management on competitive advantage by moderating role of information technology. Computer Standards \& Interfaces, 63, 67-82.

[65] Sekaran, U. Bougie (2010). Research methods for business: A skill building approach.

[66] Singh, M., Verma, A., \& Sharma, N. (2018). Multi-objective noise estimator for the applications of de-noising and segmentation of MRI data. Biomedical Signal Processing and Control, 46, 249-259.

[67] Stafford, M. R. (1996). Demographic discriminators of service quality in the banking industry. Journal of services marketing.

[68] Stylidis, D., Kokho Sit, J., \& Biran, A. (2018). Residents' place image: a meaningful psychographic variable for tourism segmentation?. Journal of Travel \& Tourism Marketing, 35 (6), 715-725.

[69] Uncles, M. D., Dowling, G. R., \& Hammond, K. (2003). Customer loyalty and customer loyalty programs. Journal of consumer marketing.

[70] Verbeke, A., \& Kano, L. (2016). An internalization theory perspective on the global and regional strategies of multinational enterprises. Journal of World Business, 51 (1), 83-92.

[71] Vidili, I. (2021). Customer Experience: The New Competitive Advantage for Companies That Want Their Customer at the Center of Their Business. In Handbook of Research on User Experience in Web 2.0 Technologies and Its Impact on Universities and Businesses (pp. 183-209). IGI Global.

[72] Zakaria, I., Rahman, B. A., Othman, A. K., Yunus, N. A. M., Dzulkipli, M. R., \& Osman, M. A. F. (2014). The relationship between loyalty program, customer satisfaction and customer loyalty in retail industry: A case study. Procedia-Social and Behavioral Sciences, 129, 23-30. 
[73] Ze, Y., Abbas, H., Hussain, T., \& Jiao, H. (2018). Analyzing the differentiation strategies of big companies competing with each other. Strategic Management, 23 (3), 25-37.
[74] Zhou, J., Wei, J., \& Xu, B. (2021). Customer segmentation by web content mining. Journal of Retailing and Consumer Services, 61, 102588. 